\title{
Investigation of Early Vocabulary Development of a Persian Speaking Child at Age 2 Years Old in IRAN
}

\author{
Hajar SHAHHOSEINI \\ Islamic Azad University, Iran \\ h.hoseni90@yahoo.com
}

\begin{abstract}
This study investigates the development of early Persian vocabulary in the process of first language acquisition in case of an Iranian child at age 2 . The child was named Melica in this paper and her speech was observed for the period of 6 months. The outcomes show that Melica could produce about 150 words and understand many more when she was 2 years old. Also she understood such meanings as "on", "under", and "in". At that age, she mostly produced nouns, which represented more than half of her vocabulary. Observed for a period of six months, Melica showed a gradual development in word as well as in sentence production, though some discrepancies in the use of certain words, such as developmental errors and overextensions, were also reported.
\end{abstract}

Keywords: early vocabulary; word combinations; acquisition; learning

\section{Povzetek}

Študija preučuje razvoj besedišča pri iranski dveletnici, katere materni jezik je perzijščina. Deklici je $v$ študiji ime Melica. Njen govor je bil spremljan 6 mesecev s pričetkom pri njenem drugem rojstnem dnevu. Melica je ob pričetku študije aktivno uporabljala približno 150 besed in poznala pomene kot so "na", "pod" in " $v$ ". V tem času je povečini uporabljala samoglasniške besede, ki so predstavljale več kot polovico njenega celotnega besedišča. $V$ obdobju šestih mesecev je napredovala tako $v$ številu aktivno uporabljanih besed kot tudi v številu izraženih stavkov, čeprav avtor poroča tudi o nekaterih nepravilnostih, kot so na primer razvojne napake pri izgovarjavi in preobširno pojmovanje besed.

Ključne besede: zgodnje besedišče; besedne zveze; usvajanje; učenje 


\section{Introduction}

Language acquisition is a skill rather than the result of a learning process. Although parents may try to strengthen the speech of their child by their own verbal behavior, facial expressions or other gestures, this can not be the primary reason for the child to become a fluent speaker in his or her native language. The relationship between children and parents may of course stimulate the native language learning. Children's exposure to the native language environment and in a social context help children develop their language.

Children appear to learn language in the same way as they learn to walk. They learn vocabulary, grammatical structures, phonological characteristics, morphological and pragmatic relations gradually. Many researches show that infants at the age of three to four months can distinguish a voice with verbal information from the one with nonverbal information, and can understand differences between /t/ (ت) and /d/ (د); or /t/ (ت) and /k/ (ك). As Fromkin (1983, p. 326) states, "children do not wake up one morning with a fully formed grammar in their heads or with all the "rules" of social and communicative intercourse". Language is acquired at stages and it is generally thought that every successive stage gets closer to the language of an adult.

At the age of about 12 months, a child tries to imitate the words that they hear. At that stage a child starts learning words gradually. Until the age of 2 learnt words are generally context bound (Barrett, et al., 1991; Dromi, 1987). This study investigates early vocabulary development of a Persian speaking child at the age of 2 .

\section{Literature review}

Language acquisition is a "process whereby children achieve a fluent control of their native language" (Varshney, 2003, p. 307). Surveys of a child's first 40-50 words reported in diary studies for a variety of languages show that a child's first collection of words fall into a fairly small number of categories (Clark, 1979), which consist of people, food, body parts, clothing, animals, vehicles, toys, household objects, routines, and activities or states. Clark (1973) further stresses clear, objective perceptual features as the criteria bases for word applications, and defines lexical innovations as the result of lexical gaps (Clark, 1981). She discusses lexical gaps in two major headings, namely, momentary or chronic. Clark and her colleagues (Clark, 1981, 1982, 1983, 1991, 1993; Clark \& Hecht, 1982; Becker, 1994) also discuss the principles and mechanisms that guide a child's lexical innovation strategies.

The first principle is the principle of productivity. The principle basicly assumes that "those word-formation devices used most often by adults in word innovations are the most productive in the language for constructing new word-forms" (Clark \& Hecht, 1982 , p. 6), and that more productive word formation devices are acquired earlier than 
the less productive ones (Clark, 1995). For instance, children with English as their first language should, when constructing new agent nouns, acquire the agentive ending -er earlier than the agentive ending -ist, as the former one is supposed to be more productive (Clark 1995).

The second principle is the principle of simplicity. According to this principle, simple forms which require the least modifications on its root are the easiest to acquire. For instance, the typical agent and instrument compounds, the children innovated during the early stages of their lexical development are composed of simple structure of noun or verb + noun as in the example of fire-man (Clark \& Hecht, 1982).

The third principle is the principle of semantic transparency. On the basis of this theory Clark (1993) indicates that people interpret and coin new words by relying to roots and affixes that are transparent in meaning. In this sense, a child is expected to produce the word animal doctor instead of veterinarian because the former word is straightforwardly derived from the two already known words: doctor and animal. Semantic transparency thus "underlines the dynamic nature of children's lexicon acquisition process because children constantly map massive numbers of word meanings onto words from their early years and each new word analysed enlarges the lexicon storage potentially available when children construct innovative words" (Clark, 1993, p. 116).

According to Chomsky (2009), language acquisition is a matter of growth and maturation of relatively fixed capacities, under appropriate external conditions. The form of language acquisition and the use of the acquired language are largely determined by internal factors; it is because of the fundamental correspondence of all human languages, because of the fact that "human beings are the same, wherever they may be", that a child can learn any language (Chomsky, 2009, pp. 101-102). The functioning of the language capacity is, furthermore, optimal at a certain critical period of intellectual development. In addition, the term language acquisition is generally used without qualification for the process which results in the knowledge of one's native language (or native languages). It is conceivable that the acquisition of a foreign language, may it be learned systematically at school or not, proceeds in quite a different way. Indeed, as we have seen, "the acquisition of one's native language after the alleged 'critical age' for language acquisition may differ, for neurophysiologic reasons, from the normal child's acquisition of his native language". (Lyons, 1981, p. 252)

\subsection{Important characteristics of language acquisition}

Acquisition is thought to be a predisposition, the children's ability to learn something without being taught about it. It is in general the innate capacity of every human being. 
Every human being has the ability to learn the language they are born with. The ability is physical, just like the ability to walk. Nevertheless, teaching is also naturally involved in the process of language development. Teaching is done by parents, teachers, and all the surrounding people for a child to gain knowledge and to perform the language. Without such stimulation, which also carries social and cultural information, a child would not be able to do the work, such as speaking or reading.

The innate language ability is still observable in the fact that a human can at any stage of language use create words, phrases or sentences that they have never experienced before.

\subsection{Stages of language development}

According to Owens (2001, p. 72), there are six stages of language development generally recognized to govern first language development:

- pre-linguistic stage with crying, cooing and babbling

- linguistic stage

- holophrastic stage

- two-word stage

- telegraphic stage

- immediate development stage

- adult stage

The onset of the linguistic stage is what is called single-word or holophrastic stage although, through the second and third phases of pre-linguistic stage, i.e., cooing and babbling, distinct language specific sounds begin to emerge (Carroll, 2008). Babbling is thought to be a form of play in which various sounds are practiced and mastered before they are put to communicative usage (Owens, 2001). There are several reasons to think that babbling is not communicative.

One reason is that sounds made during babbling are similar to but phonologically sloppier than the corresponding sounds made later on. While the "ma" of the 7 month old and that of 18 month old may sound similar, when the two utterances are examined spectrographically, the earlier sound is generally sloppier and exhibits a greater range of acoustic properties than true speech (Carroll, 2008). Another reason is that infants have been found to babble more often when an adult is not present than when one is present (Nakajima, 1975); for instance, babies often babble in the crib when awakening and before falling asleep, and since no one is present, it is difficult to see these as communicative acts (Carroll, 2008). The emergence of the first words or vocalizations does not signal the end of vocalizations such as babbling, jargon, and phonetically consistent forms (Owens, 2001), and all three continue to be produced by the child throughout their second year of life (Robb, Bauer \& Tyler, 1994), during which the child increases his or her vocabulary and begins to combine words within a single utterance. 
Gradually the child realizes that a word refers not to a single referent but to a related group of referents (Oviatt, 1982).

\subsection{General characteristics of a 2-year-old child}

A child at 24 months of age can walk well, can run and stop, or step up. They can use the spoon and drink water from a glass by themselves. They can name four to five words of the body parts, answer simple questions beginning with "why" and "what", and point to pictures when instructed, or name an object when asked. A child at 24 months of age can use two to three short sentences regularly.

\subsection{Some important characteristics of the child at age of $\mathbf{2}$ for this study}

At around 2 years of age, a child's development forms its essential characteristics that can be divided into sensory and motor development, physical development, cognitive development, emotional and social development, and language.

Sensory and motor development. By the age of 2, most children can walk up the stairs one at a time, start to run, kick a ball, throw a ball overhand, and draw simple strokes with a pencil. Also, a child can climb on and down from furniture without the help of parents. Gradually, they learn to walk backwards, to turn corners, and improve their actions.

Physical development. At age of 2, a child becomes stronger and starts to look longer and leaner. They are active and energetic, but get tired easily. Their weight and height still grow fast though slower than in the year before. The movements of hands and eyes get somewhat coordinated.

Cognitive development. After their second birthday, a child gradually begins to think and reason. It is usually the year when a child starts learning to count and name colors.

Emotional and social development. From the age of 2 a child gradually learns how to manage their feelings by requiring approvals of their siblings, parents and other people around them, and by obeying their requests and commands. At this age they are easily affected by the general situation of the family. They feel confident and secure in their relationship with parents, and listen carefully when talked to with reason and logic. They also like to play with other children, do the magic puzzles and model.

Language. By age 2, a child usually uses two-word sentences, frequently make questions beginning in "what" and "why", and can produce at least 60 words. They learn additional 90 words within the period of 6 months to reach a vocabulary of at least 150 words when two and a half. 


\subsection{Study question}

In this study we examine how well a particular two-year-old child fits into the above described general developmental stages.

\section{Study methodology}

This study concentrates on the development of early vocabulary in the first language acquisition of an Iranian child, who is a speaker of Persian. Data for this study were collected to a) classify the child's vocabulary, its scope and content, and to b) compare the child's L1 vocabulary in Persian to the data for L1 vocabulary in English, and c) to look into general differences and similarities between vocabulary of Persian as L1 and English as L1, and discuss the differences in the process of acquisition of the two languages.

\subsection{Participant}

The subject of this study is a girl named Melica. She is 2 years old and lives with her elder brother ( 5 years), mother and father in a family of four in the city of Bushehr. The dominant language they use at home is Farsi. Melica does not attend kindergarden or nursery, and does not have much contact with other children either. She is a normally developed child. In order to collect data, we visited Melica three times a week for six months.

\subsection{Method and procedures}

During the visits, we recorded the child's talk. Sometimes we had a short conversation of about 5 minutes with the child. The conversation was in Persian and questions were about familiar, ordinary things. Recordings helped recognize and count the number of words the child produced. we also made notes on behavioural observations and speech characteristics during the period of six months. With the analysis of the recordings we could gain information on the number of new words per day, per month, and per six months.

Besides the recordings, we also used parents' reports to assess the girls vocabulary. Parents were instructed to observe the girl carefully for the whole period of 6 months.

Finally, we could use a 20-minute home video-recording with Melica in a natural surrounding to evaluate her vocabulary. The camera was set in the corner of a living room to record the child's spontaneous speech. 


\section{Results and Analysis}

This study deals with the development of early L1 vocabulary in case of one Persian speaking 2-year-old Iranian.

The main objective in this study is to identify the development of early vocabulary, and recognize the number of words in Persian as L1. Results of this study show that by the age of 2 the child has the ability to produce several different words. This production of words presumably depends on various factors such as child's genetics, physical growth, home and other surrounding environment, and other factors. By her second birthday the child is able to name her toys, some foods, animals, and members of family (father and mother). The analysis of the recorded voice shows that the number of words the child used was approximately 150 .

In the period of six months, it could be observed that the child gradually started using pronouns like "me", "you", "him", and "he", though they still got confused, especially when Melica was talking about herself. She also gradually started understanding prepositions like "on", "under" and "back". Her ability to express negative expressions also increased.

In the period of six months, it could be observed that the child gradually started using pronouns like "me", "you", "him", and "he". The pronouns were sometimes used in a wrong way, especially when she was talking about herself. Besides, Melica gradually started to understand prepositions like "on", "under" and "back".

Her ability to express negative expressions also increased. While at the beginning of this study she could only use "no", she later on started using expressions within a sentence such as "Don't do that.", "This is not (my car)."

The child could already produce some complex questions, as for example "Where did the sun go?" or "Why is she crying?". It is interesting that sometimes she was satisfied with the answer she got, and sometimes not. In the latter case, the parents usually thought their answer might not have been satisfactory but in fact it seemed as if the child liked to repeat the same question because she liked the answer, or because she simply enjoyed making conversation. Such reasons could also apply to cases like when Melica said "I saw ..., I saw ..., I saw", then paused and started from the beginning.

Melica generally used short, two- to three-word phrases. She could understand most of ordinary, everyday words, and could produce words such as "mom", "dad", "shoes", "hat", "mercy", "finish", and others. She then produced various short sentences using those words. Her common sentences were "I am hungry." or "I want to go park", "Where is my doll?", etc. 
Table 1: Some common words that Melica produced at age 2

\begin{tabular}{ll}
\hline Semantic field & Expressions \\
\hline Family & $\begin{array}{l}\text { ameh (aunt), madar joon (grandma), mama (mom), } \\
\text { baba (dad), amoo (uncle), ni ni (baby), dostam (my } \\
\text { friend), bacheh (child) } \\
\text { keik (cookie), ab miveh (juice), shir (milk), } \\
\text { sharbat (syrups), bastani (ice cream), nan (bread), } \\
\text { polo (rice) }\end{array}$ \\
gorbeh (cat), sag (dog), joojeh (chicken) \\
Animals & $\begin{array}{l}\text { aroosak (doll), moama (puzzle), sag (puppy), } \\
\text { mashin (car) } \\
\text { bala (up), paeen (down), } \\
\text { toop bazi kardn (playing with ball), } \\
\text { Activity }\end{array} \quad \begin{array}{l}\text { savidan run seh charkheh bazi (play with tricycle) } \\
\text { tamam (finish), mamnoon (thank you) } \\
\text { kolah (hat), otagh (room), Aroosakam kojast? (Where } \\
\text { is my doll?), darad (hurt), khordam (eat), } \\
\text { maghazeh (store), dastam (my hand) }\end{array}$ \\
\hline
\end{tabular}

Table 1 shows the common words that Melica used during the study. With those words she made sentences like كيك تمام شد keak temam shed "This cake is over." or اين هايو aan hapew aset "This is a dog.".

Table 2: Vowel or consonant misarticulation. Melica's examples of developmental errors produced during the study (between the ages of 2 and 2 and a half).

\begin{tabular}{|c|c|c|}
\hline Produced word & Correct word & Meaning in English \\
\hline 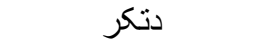 & 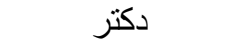 & doctor \\
\hline 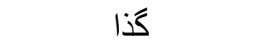 & 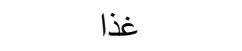 & food \\
\hline بلم بارك & برم يارك & go to park \\
\hline بازى & بازى & play \\
\hline كاشق & قاشق & spoon \\
\hline 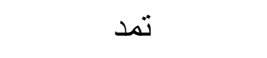 & كمد & closet \\
\hline بلِو & هلو & peach \\
\hline
\end{tabular}

Table 2 shows examples of the sounds that were misarticulated. Misarticulations which are appropriate for a certain age are called developmental errors. In case of Melica's typical developmental errors, similar sounds were commonly used instead of the expected sounds, or else, word sounds got scrambled. In the word غذا gheda "food", 
for example, the child articulated the sound $\hat{\xi}$ gu instead of $\dot{\varepsilon} g h$, and therefore the word غذا gheda was pronounced in the form of is guda. Also, young speakers of Persian at this age commonly use $J /$ instead of $J r$, which was also typical for Melica, who pronounced بل belm instead of برم ل berm "I'll go". This means that the child has the ability to pronounce $J /$ better than $J r$, and though Melica recognized the difference between the two sounds, she was not able to articulate the word correctly at the beginning of the study. Gradually she has learnt to use the correct vowel and consonant.

Table 3: Some non-typical expressions and sentences that Melica produced at age 2.

\begin{tabular}{|c|c|c|}
\hline Special phrases & Romanization & Meaning in English \\
\hline دعو اكن & daava kon & A person who quarrels \\
\hline ماما غذا يُزيد & Mama ghaza pazid. & Mother cooks the food. \\
\hline ظرف شو & zarf shoo & A person who washes the dishes \\
\hline دتكر رفتم & Dotcor raftam. & I go to the doctor. \\
\hline 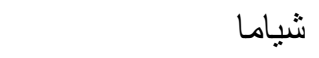 & Shiamma. & I want milk. \\
\hline فردا به يارك ميروم & Farda be park raftam. & I went to the park yesterday. \\
\hline كخ مخ & Kakh makh & I want Yakhmak. \\
\hline دوخرجه ر انى & Dokharcheh rani. & I want to ride a bike. \\
\hline
\end{tabular}

Table 3 shows the non-typical expressions Melica often used during the study, and her two-word sentences from those expressions. Sentences conveyed the meaning and were grammatically correct but generally demand a slight change in vocabulary. For example, Melica would use (1) instead of (2).

كخ مخ،شو ،رانهيزيدن (1)

kekh mekh, shew, ran, pezaden

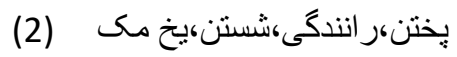
pekhetn, ranendegua, shesten, akh meke

The study results confirmed that a child gradually adjusts his or her speech to become similar to adult speech. 


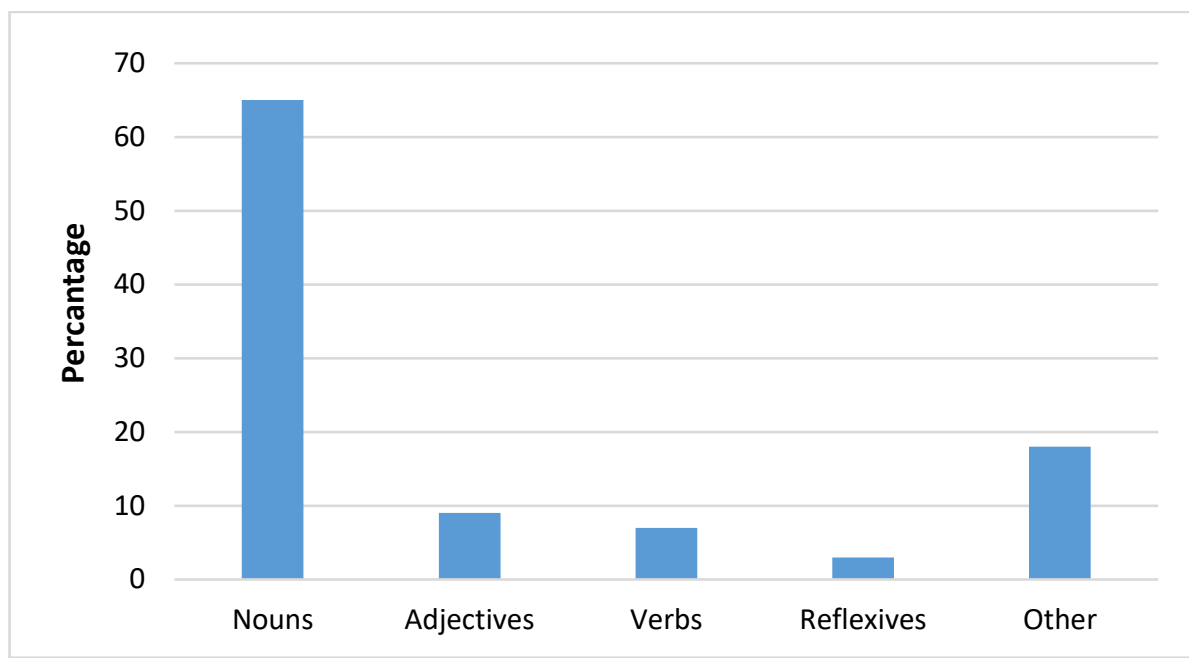

Figure 1: The appearance of word classes produced by Melica during the study

Figure 1 shows the rate of appearance of most common word groups used ba Melica during the whole period of the study. According to this figure, nouns are most highly represented in the vocabulary of the child and reach to as high as $64 \%$ of all the words produced. The frequency is second highest with adjetives $(9 \%)$ and is followed by verbs $(7 \%)$, reflexives $(2,23 \%)$, and all the rest of the words $(17,56 \%)$.

Table 4: Acquisition progress by a two-yer-old Melica during 6 months

\begin{tabular}{lcccccc}
\hline & \multicolumn{5}{c}{ Percentage of words and sentences per month } \\
\cline { 2 - 7 } & M1 & M2 & M3 & M4 & M5 & M6 \\
\hline Word production & $32 \%$ & $43 \%$ & $49 \%$ & $52 \%$ & $60 \%$ & $75 \%$ \\
Sentence production & $14 \%$ & $16 \%$ & $19 \%$ & $21 \%$ & $22 \%$ & $25 \%$ \\
\hline
\end{tabular}

Table 4 indicates that learning L1 vocabulary in the third year is progressive. The scope of vocabulary at the age of 2 and a half represents $100 \%$ of all utterances, of which $75 \%$ are words and $25 \%$ are sentences. Looking back to the detailed results of this longitudinal study, it is clear that the rise of the percentage, cf. the growth of the vocabulary, is gradual for both single words as well as sentences. Word production percentage rises from $32 \%$ in the first month after the child's second birthday, to $43 \%$ in the second, $49 \%$ in the third, $52 \%$ in the fourth, $60 \%$ in the fifth, and to $75 \%$ of all uttered expressions in the last, sixth month of the study. The same rising tendency is observed for sentence production, which was up to $14 \%$ at the beginning of the study, and gradually rising to $25 \%$ at the end of a 6 -month period. 
Table 5: Overextension of some words at the child at 2 years old in Persian

\begin{tabular}{lll}
\hline Word & Romanization & Overextension \\
\hline يليس pelas & police, military, solider \\
هابو hapo & cow, dog, fox, cat \\
ددى dadi & every girl, daughter \\
مار mar & worm, scorpion, millipede \\
در dar dar & place out of house, park, store \\
هلو holoo & nectarine, starvation, peach \\
& ba bai & sheep, goat \\
\hline
\end{tabular}

Table 5 shows that the child when 2 years old overextends some words based on shape and color. For example, Melica used the word "peach" for three types of fruits, cf. nectarine, starvation, and peach, and the word "police" for police, military, and soliders.

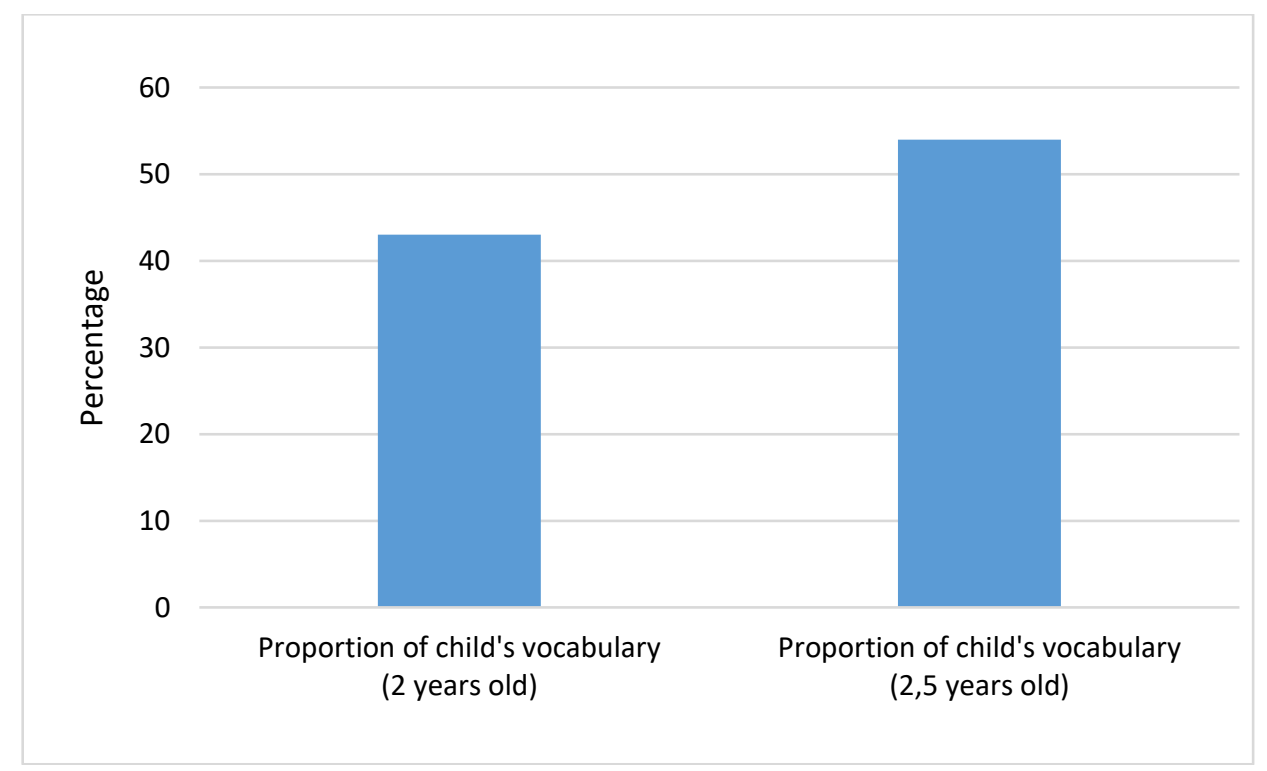

Figure 2: Development of early vocabulary in L1 acquisition; the case of Melica

Figure 2 shows that the number of words spoken by Melica confirms the general idea that children have a language developmental path. While the proportion of the vocabulary of the child at the age of 2 was at $43 \%$, this proportion increased to $54 \%$ in the period of six months. 
By the end of the second year, a child tends to use words like "me" or "myself" very often. For example, when Melica's mother wanted to change Melica's clothes, close her shoes, or feed her, Melica would say "myself". The " $m$ " that comes after itself in خودم khewdem is very important. Psychologically Melica wanted to say that they could do that on their own, or that they wanted to make their own decision.

In this age Melica could use the past form of verbs and nouns in plural forms. She liked the question words such as "what, who, why". She could understand and solve simple problems, and could describe simple events to her mother.

The results of this case study suggest that the child learned many new words by listening to her parents, especially to her, and other people, recorded stories, etc. At this age, Melica could guess many words from the context and could recognize many more words than he or she actually used.

She has learned many new expressions such as "brother", "uncle", "animals", "toys", words for body parts and clothes. Just like other children of her age, Melica was able to describe her emotions such as 'happy', 'sad, and 'angry'. Many concepts such as 'longer', 'smaller', and 'bigger' become understandable to her, and she could also name several colors.

In short, Melica at this age could communicate, play, role play, and managed short negotiations with other children and her parents.

\section{Conclusions}

This study surveyed the development of the L1 vocabulary of an Persian speaking Iranian child at age 2 during six months. Results show that the child was able to gradually expand her actively used vocabulary from approximately 150 words in the time of her second birthday to 210 within a six month period, and her understanding of words was even greater. She was also able to increase the number of sentences she used during this period.

According to Clark (1979), a child may be able to produce anywhere from 100 to 600 distinct words by their second birthday. By the age six, they have a vocabulary of around 14,000 in comprehension, with somewhat fewer in production. These numbers imply that they acquire words between age two and age six at a rate of nine to ten words a day.

At this age the child expands the number of vocabulary through various stimulants; by listening to their parent's speech, the speech of their peers, stories, and others. Results of this study show that the growth of the vocabulary is constant though there appear some discrepancies in the use of certain words. Most common discrepancies are the misarticulation, which happens due to developmental errors, and misuse of the 
meaning due to the overextension of a word. In the latter case, the majority of vocabulary seem to be based on some kind of similarity between the adult referent for the term overextended and the child target on a particular occasion (Clark, 1973a; Anglin, 1976).

\section{References}

Anglin, J. M. (1976). Word, object, and conceptual development. New York: Norton.

Anglin, J. M. (1993). Vocabulary development: A morphological analysis. Monographs of the Society for Research in Child Development 58 (serial no. 238).

Barret, M. D., Harris, M., \& Chasin , J. ( 1991). Early lexical development and maternal speech: A comparison of the children's initial and subsequent uses of words. Journal of Child Language, 18, 21-40.

Carroll, D. W. (2008). Psychology of language (5th ed.). Canada: Thomson Wardsworth.

Clark, E. V. (1973a). What's in a word? On the child's acquisition of semantics in his first language. In T. E. Moore (Ed.), Cognitive development and the acquisition of language. New York: Academic Press.

Clark, E. V. (1979). Building a vocabulary: Words for objects, actions, and relations. In P. Fletcher \& M. Garman (Eds.), Language acquisition (pp. 149-160). Cambridge: Cambridge University Press.

Clark, E. V. (1981). Negative verbs in children's speech. In W. Klein \& W. J. M. Levelt (Eds.), Crossing the boundaries in linguistics (pp. 253-264). Dordrecht: Reidel.

Clark, E. V. (1982). Language change during language acquisition. In M. E. Lamb \& A. L. Brown (Eds.), Advances in developmental psychology, vol. II (pp. 173-197). Hillsdale, NJ: Lawrence Erlbaum.

Clark, E. V. (1993). The lexicon in acquisition. Cambridge: Cambridge University Press.

Clark, E. V., Hecht, B. F., \& Mulford, R. C. (1986). Acquiring complex compounds: Affixes and word order in English. Linguistics, 24, 7-29.

Chomsky, N. (2009). Cartesian Linguistics: A Chapter in the History of Rationalist Thought. Third Edition. America: Cambridge University Press.

Dromi, E. (1987). Early lexical development. New York Cambridge University Press.

Fromkin, V. (1983). An Introduction to Language. Third Edition. New York: CBS College Publishing.

Lyons, J. (1981). Language and Linguistics: An Introduction. America: Cambridge University Press.

Nakazimara, S. (1975). Phonemicization and symbolization in language development. In E. H. Lenneberg \& E. Lennenberg (Eds.), Foundations of language development (pp. 181-187). New York: Academic Press.

Oviatt, S. (1982). Inferring what words mean: Early development in infants comprehension of common object names. Child Development, 53, 274-277. 
Robb, M. P., Bauer, H. R., \& Tyler, A. A. (1994). A quantitative analysis of the single word stage. First Language, 14, 37-48.

Varshney, R. L. (2003). An Introductory Textbook of Linguistics \& Phonetic. India: Student Store. 